Portland State University

PDXScholar

\title{
An Investigation into Japan's Population: The Current State of Decline
}

Joel Stewart

Portland State University

Follow this and additional works at: https://pdxscholar.library.pdx.edu/geog_masterpapers

Part of the Human Geography Commons

Let us know how access to this document benefits you.

\section{Recommended Citation}

Stewart, Joel, "An Investigation into Japan's Population: The Current State of Decline" (2007). Geography Masters Research Papers. 17.

https://pdxscholar.library.pdx.edu/geog_masterpapers/17

10.15760/geogmaster.16

This Paper is brought to you for free and open access. It has been accepted for inclusion in Geography Masters Research Papers by an authorized administrator of PDXScholar. Please contact us if we can make this document more accessible: pdxscholar@pdx.edu. 
An Investigation into Japan's Population: The Current State of Decline

Joel Stewart

Submitted for partial fulfillment of Master of Science degree in Geography Portland State University

Approved by:

Martha Works, Advisor

Martha Works, Professor of Geography

Date: 


\section{Table of Contents}

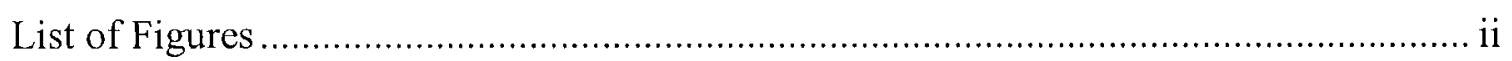

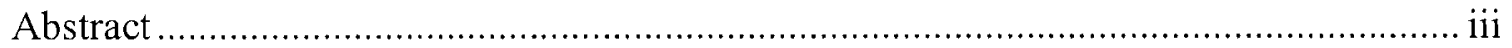

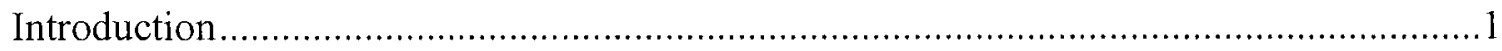

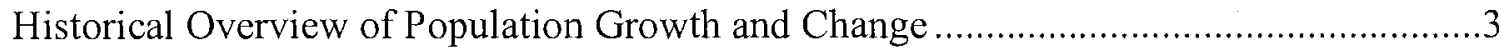

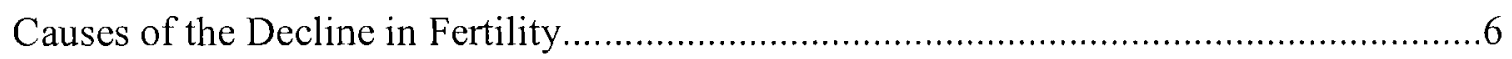

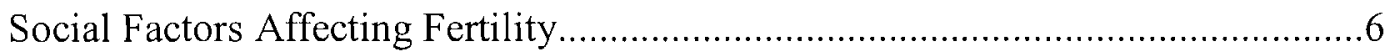

Attitudes, Stereotypes, and Gender Roles..................................................9

Economic Factors Affecting Social Fertility ............................................. 11

Policies Addressing the Shrinking Population and Workforce.....................................13

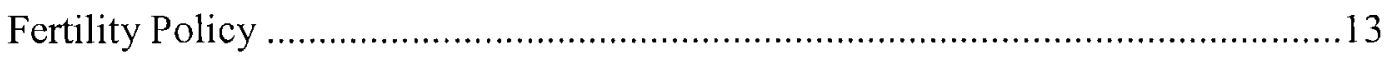

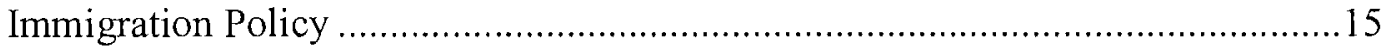

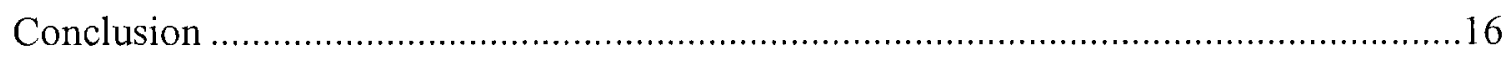

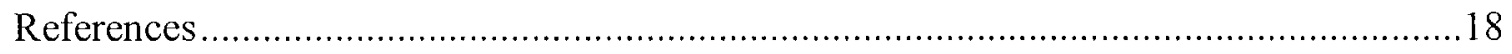




\section{List of Figures}

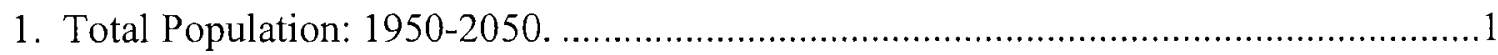

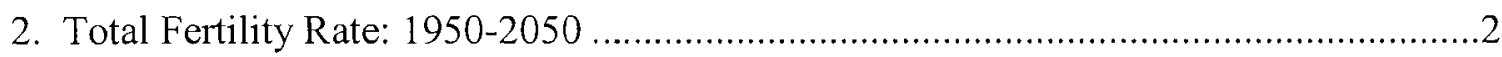

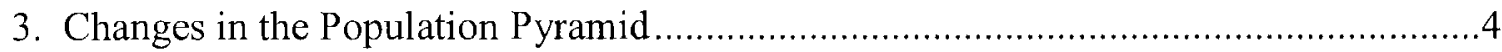

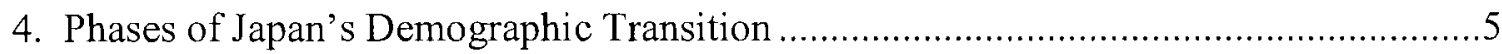

5. Changes in Marriage and Divorce Rate .................................................................

6. Relationship between TFR and Men's Time Spent for Family Work .......................11

\section{List of Tables}

1. Major Actions Taken by the Government Toward Declining Fertility Rate 14 


\begin{abstract}
Japan is facing a demographic crisis. The population is aging and shrinking at a considerable pace despite the government's efforts to curtail the problem. This rapid change in the demographic structure of Japan is bound to have stark implications on the society and economy of Japan. The objective of this paper is to understand the issues that allowed this impeding crisis to come about. A thorough examination of the current literature on Japan's fertility and population issues revealed that a number of various factors are causing the impending crisis. Some of the factors determined to be affecting the population dilemma include the prevailing social conditions, attitudes, and practices of the Japanese people, in addition to economic realities that constrain many people's choices. The government of Japan has, over the past fifteen years, enacted a number of policies to address the population crisis. However, these appear to have done little to mitigate the decline in fertility. It is apparent that greater attention must be given to the underlying issues that are causing the crisis. If the situation is to improve, a change in the current mindset of how to amend the population problem must occur.
\end{abstract}




\section{Introduction}

In the coming decades Japan will undergo significant demographic changes. Population peaked in 2006 at slightly over 128 million, and could shrink below 100 million by 2050 if current trends continue (Figure 1). The coming hyper-aged and depopulating society will have a drastic impact on Japan's labor force and could have grave economic and social consequences. A combination of both social and economic factors has reduced fertility rates to the lowest in Japan's history. The current fertility rate is 1.3 , well below the replacement fertility rate of 2.1 , and it is projected to continue to decline, thus creating the current demographic crises (Population Reference Bureau, 2006).

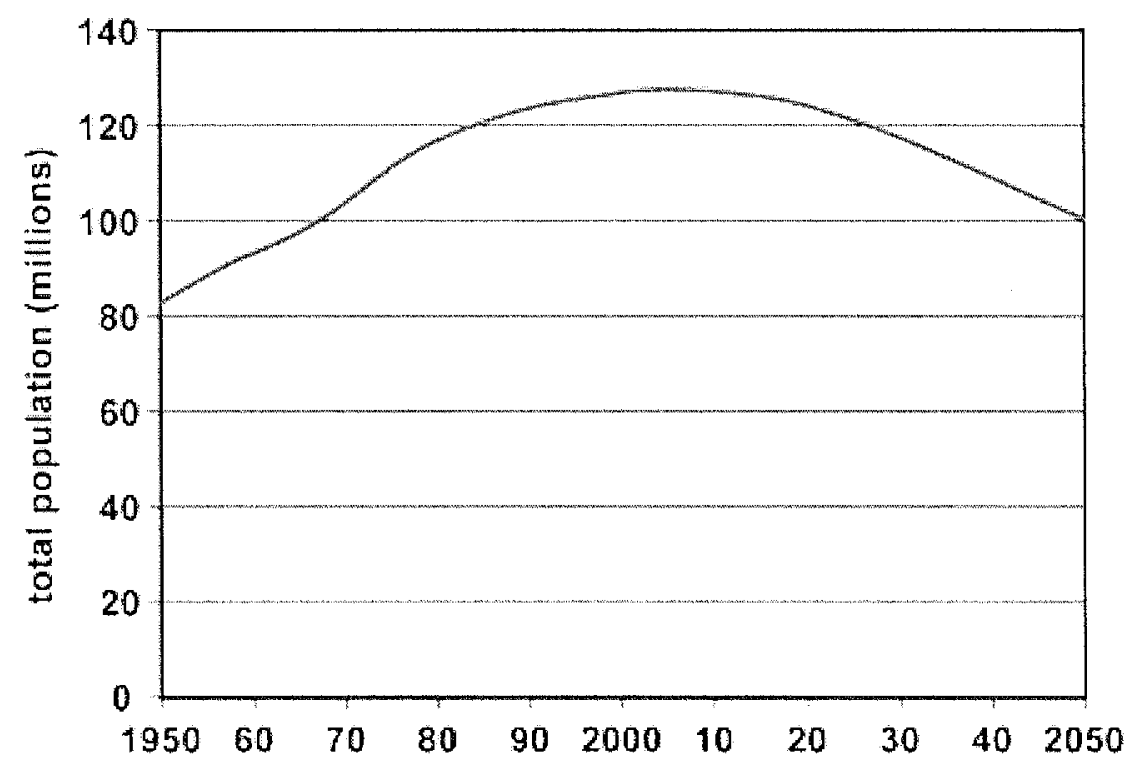

Figure 1. Total Population: 1950-2050. Source: NIPSSR, Population Statistics of Japan 2003 
During the 1970's and 1980's the Japanese government took a wait-and-see approach to the declining fertility rate. The government realized there was a decline, but assumed it would correct itself. A 1989 study conducted by the Ministry of Health and Labor revealed that the fertility rate had fallen to the "shocking" level of 1.57 prompting the first measures to be taken to address the situation. Over the next eighteen years the Japanese government enacted policies to rectify the falling fertility rate, yet it continued to decline (Figure 2). The objective of this paper is to understand the issues that allowed this impeding crisis to come about.

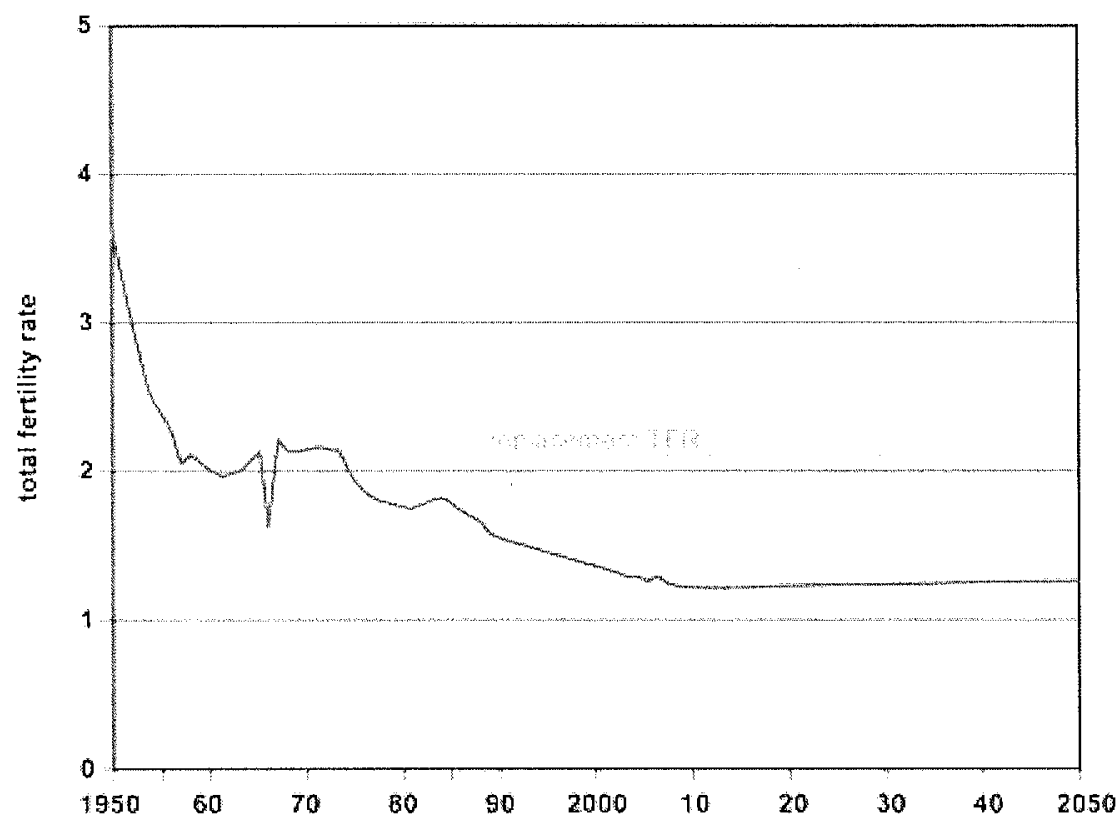

Figure 2. Total Fertility Rate: 1950-2050. Source: Ministry of Health, Labor, and Welfare, 2005.

The demographic challenge facing Japan is two-fold. The population is both shrinking and aging at a considerable pace. There is concern from the government about maintaining the social security system in addition to a loss of economic strength. This 
concern extends to the private sector where businesses are worried about having enough workers and consumers to keep the economy from withering. Indeed, the labor force is expected to shrink by $10 \%$ over the next 25 years (Chapple, 2004). Exacerbating this problem is the rapidly growing percentage of elderly in the population. Currently the elderly, those aged 65 and older, make up $21 \%$ of the total population (Statistical Handbook of Japan, 2005). By 2050 this number is projected to grow to $35.7 \%$ (Figure 3). Added to this is the increase in the age dependency ratio, "the ratio of the elderly population aged 65 or more to the working-age population aged 15-64" (Atoh, 2000). This ratio is expected to rise from its mid 90 's level of $29 \%$ to $59 \%$ by 2050 . This means "each elderly person will be supported by only 1.3 working people in 2055 , compared with 3.3 people in 2005" (Japan Times, 2007). Perhaps the condition of the population is most accurately captured by demographer Julian Chapple of the Kyoto Sangyo University who said "the situation in Japan is fast becoming critical and proactive measures are needed urgently" (Chapple, 2004). While measures and policies have been enacted, in order to produce more effective changes further analysis of the underlying causes of the situation is needed.

\section{Historical Overview of Population Growth and Change}

An historical overview of Japan's population growth and change sets the stage for the current demographic crisis. Japan's demographic transition can roughly be divided into five phases. Prior to 1868 , the year of the Meiji Restoration, Japan was in a preindustrial period. During this phase Japan was in its pre-modern state, and the population 
of 30 million was stable because of the balance between high birthrates and high death rates (Karan, 2005).

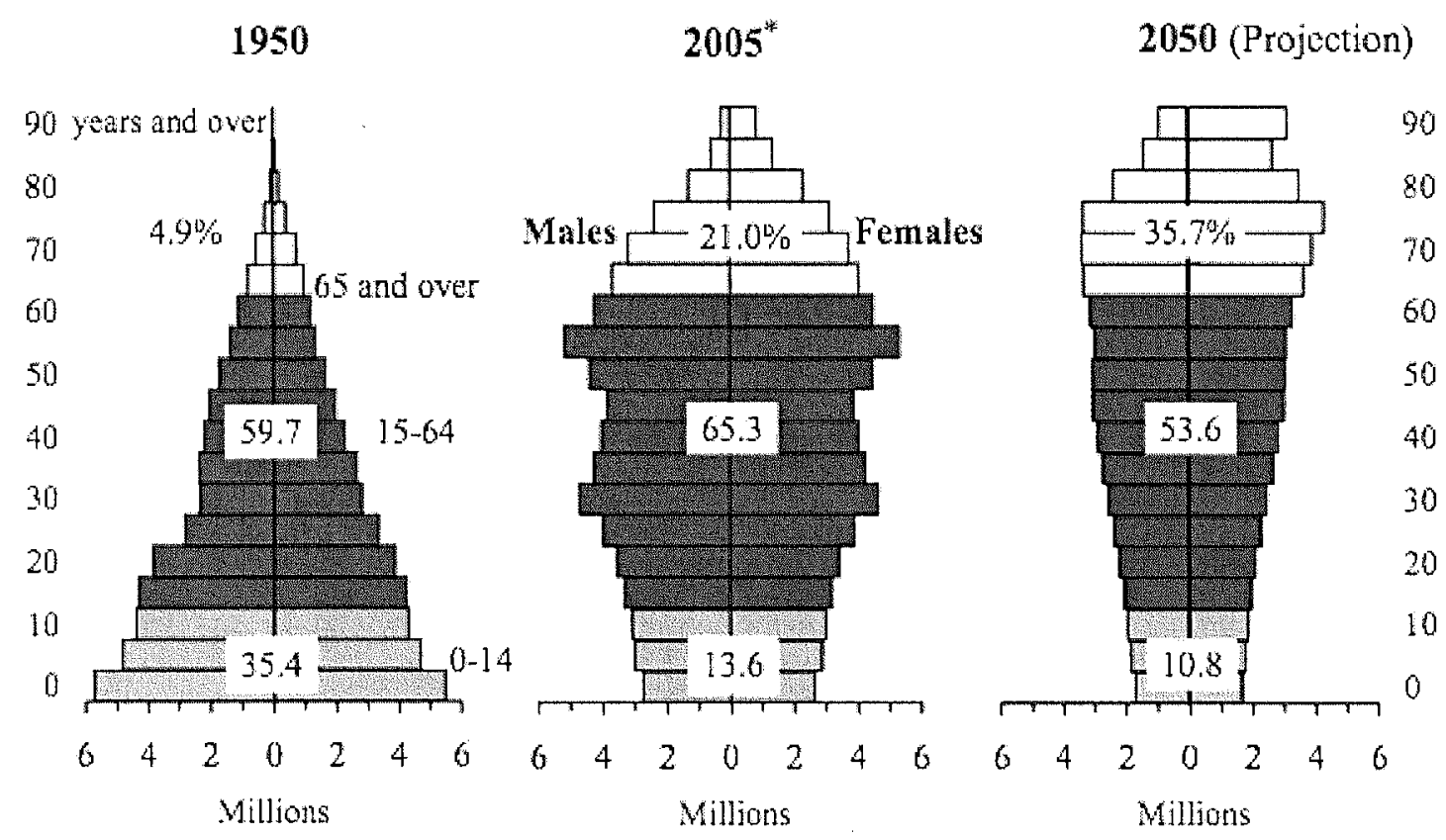

Figure 3. Changes in the Population Pyramid. Source: Ministry of Health, Labour and Welfare, 2005.

After the initial changes of the Meiji restoration during which Japan emerged as a global trading participant and shifted toward a modern society from its feudal past the population rapidly increased. During this second phase of Japan's demographic transition from 1868-1920, the development process ushered in a new era of urbanization and industrialization. Advances in science and technology caused a significant decrease in mortality, but fertility continued to remain high. As a result, the population grew to 40 million in 1887,50 million in 1911, and 55.9 million in 1920 (Figure 4). 1920 was the first year that Japan took an official census and also marks the shift into the third phase of its demographic transition. From 1920-1950 birthrates began, for the first time, to decrease slightly. The birthrate declined from 36.2 (per 1,000) in 1920 to 28.1 in 1950 . During this same time death rates fell rapidly from 25.4 (per 1,000) to 10.9 (Karan, 
2005). The rate of natural increase peaked in 1950 at 17.2 and the population reached 83.5 million.

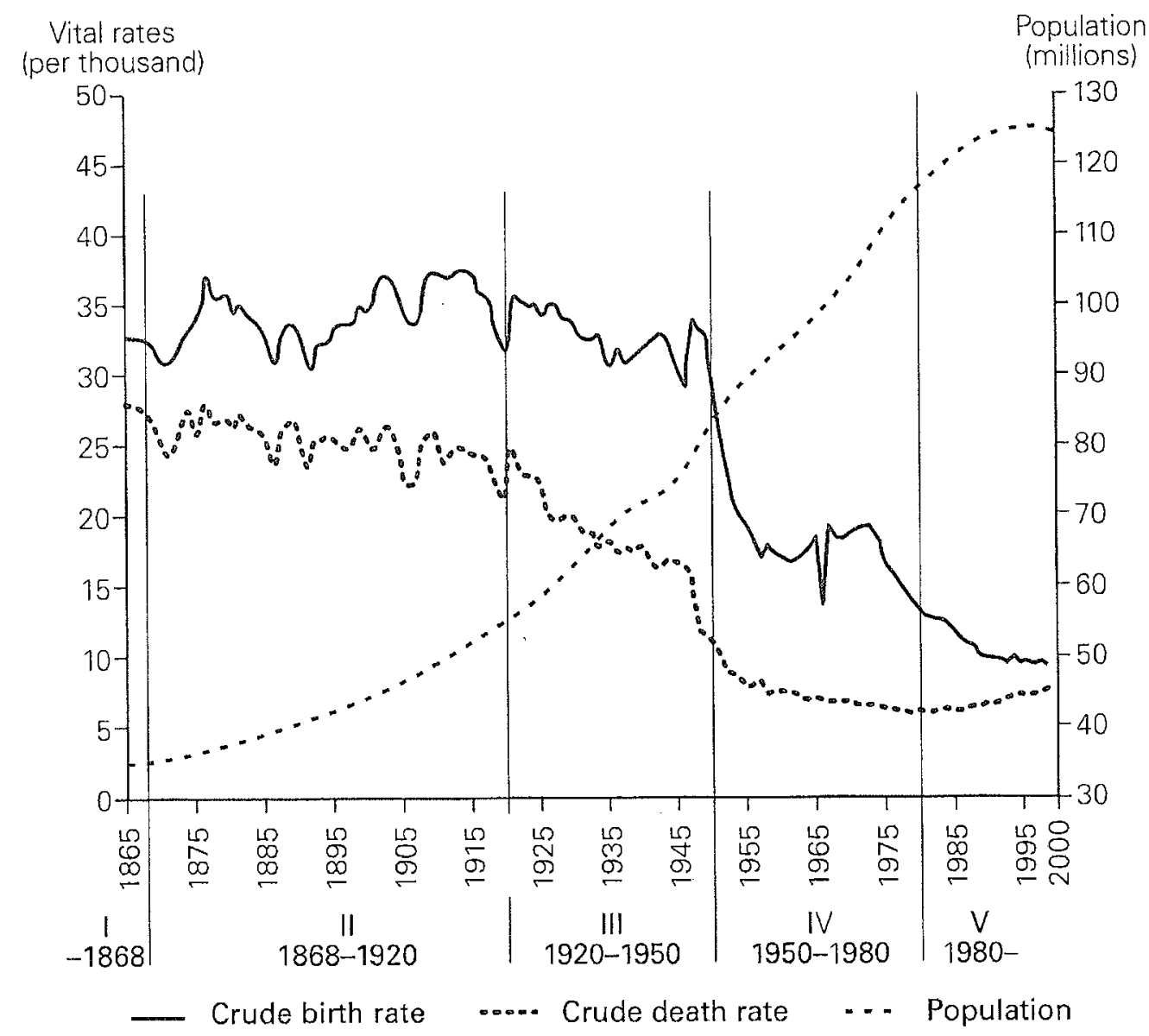

Figure 4. Phases of Japan's Demographic Transition. Source: Karan, 2005.

The fourth phase of Japan's demographic transition is characterized by the precipitous decline in fertility. The birthrate fell drastically to 13.6 in 1980 from 28.1 in 1950 (Figure 4). Death rates also continued to decrease reaching record lows of 6.2 . These factors account for the slower population growth, which grew to 116 million in 1980. The fifth phase, from 1980 to present, sees a steadying and slight increase in death rates. Yet, birthrates persist in their downward march plummeting to 8.4 in 2005 (Statistical Handbook of Japan, 2005). Declines in birthrates are a common feature of all modernizing, industrial nations. However, Japan's steady and rapid decline of birthrates 
over the past 25 years exceeds that of any other country in the world. As of 2006 Japan's population peaked at 128 million and is now marked by a negative growth rate as a result of the continuing decrease in fertility and concurrent increase in longevity.

\section{Causes of the Decline in Fertility}

There are both social and economic reasons as to why the total fertility rate has fallen so drastically in Japan. There is little doubt that these categorical causes are linked. It could be argued that social causes are the greater of the two, but each category contains significant factors that played a critical role in bringing about the precipitous decline of the fertility rate. While the two categorical causes are related they will be examined separately.

\section{Social Factors Affecting Fertility}

Shoshika is the Japanese term given to the trend toward having fewer children. This trend of the past few decades result from a number of related reasons. To begin, marriages are occurring at a later age, and with much less frequency than in the past. In the early 1970's the marriage rate, the number of persons married per thousand population, averaged 10.0 (per 1,000 population). In 2005 the rate fell to 5.7 (per 1,000 population) (Statistical Handbook of Japan, 2005) (Figure 5). In contrast, according to the National Center for Health Statistics, as of 2005 the United States had a marriage rate of 7.5 (per 1,000 population) (Center for Disease Control, 2004). In addition to the reduction in the number of marriages, the average age at which marriage occurs is increasing in Japan. In 1975 the mean age for women at first marriage was 24.7. By 
2005 the mean age climbed to 28.0 (Statistical Handbook of Japan, 2005). The delay in marriage has resulted in a postponement of childbearing, which often translates into fewer children. The average age at which women bear their first child has risen from 25.7 in 1975 to 29.1 in 2005 . All of these factors add to Shoshika, the trend of having fewer children, but what is prompting this change?

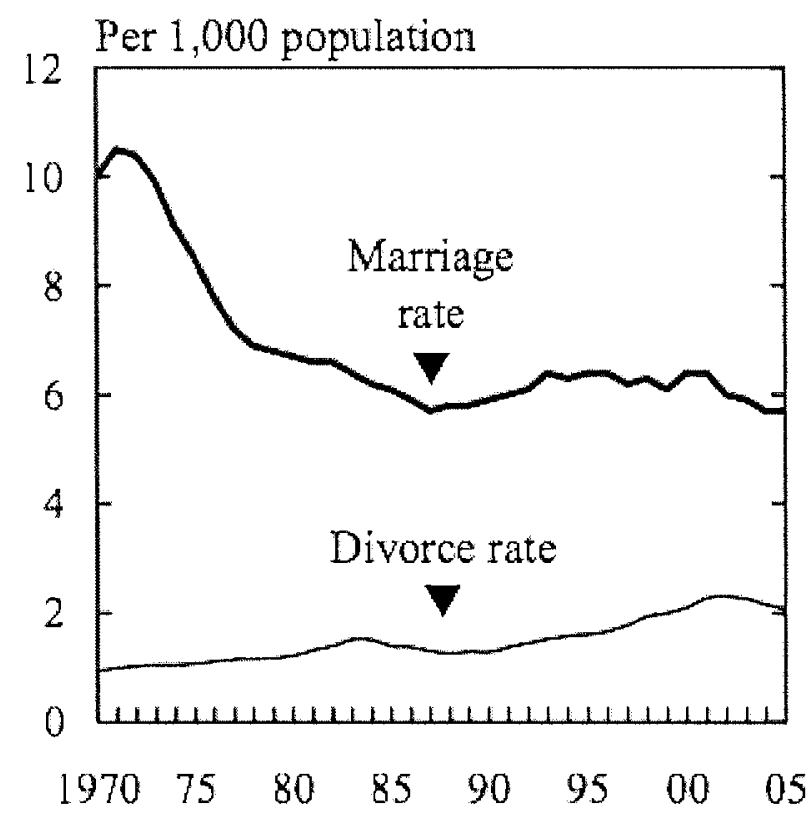

Figure 5. Changes in Marriage and Divorce Rates. Source: Ministry of Health, Labour and Welfare, 2005.

Increases in education and career opportunities for women have had a significant impact on marital patterns and birthrates in Japan. More women than ever before are earning college degrees, thereby creating more opportunities for themselves. In 1975 the rate of women having four years of college or more was $12.7 \%$. By 2005 this had advanced substantially to $36.8 \%$ (Ministry of Education, Culture, Sports, Science and Technology, 2005). Coupled with this, the proportion of women in the workforce has grown in recent decades. Among those in the workforce aged 20-59, the proportion of 
women has risen from 38.6 in 1980 to 41.3 in 2002 (Statistical Handbook of Japan, 2005). While this is not a significant increase, the noteworthy change is in the types of positions obtained by growing numbers of women. Because of the advances in educational attainment, more women are landing higher paying jobs, leading many to focus on careers rather than starting a family. Indeed the proportion of never-married women in Japan is at an all-time high. In the last fifteen years the percentage of women in their late twenties who have not married has risen from 30 to about 50 percent (Tolbert, 2000). However, there are additional social issues that are part of the shrinking fertility rate.

Many societal constraints are embedded in the Japanese culture, and more than a few Japanese women are attempting to break free of these. Japan is considered by many to be a very male dominated society. One backlash against this is the social phenomena of "womb-strike." UC Berkeley Professor of East Asian Studies Michael Zielenziger discusses this phenomenon in his book Shutting Out the Sun: How Japan Created Its Own Lost Generation. This phrase is another recently added to the list of societal problems facing Japan, and refers to women's genuine lack of desire to have children. Illustrating this point are the results of a recent survey, which found that only $27.9 \%$ of women thought childrearing would be enjoyable. The loss of free time was cited as the leading reason (Chapple, 2004).

This free time, in addition to the increase in disposable income brought on by increases in female employment has led to another term entering the lexicon; "parasite single." These "parasite singles" are women in their late 20 's and early 30 's who work for a living, but live at home with their parents. These women claim that living at home 
is the best of both worlds. They have little to no housework and pay no rent, giving them more free time and money to do with whatever they want. Masahiro Yamada, professor of sociology at Tokyo Arts and Sciences University, coined the phrase parasite single and describes their situation. "They suffer a dramatic fall in their standard of living if they get married. On average they lose two thirds of their spending money. And they also have to do housework. The gap between the two lifestyles is growing" (Scanlon, 2001). Surveys show that this demographic group of parasite singles is the most contented in Japan. For many Japanese women getting married and becoming a housewife is far less enticing and hardly incentive enough to leave this lifestyle behind.

Attitudes, Stereotypes, and Gender Roles

Attitudes and stereotypes are additional points of contention in Japanese society leading to lower birth rates. The unhappiness of some women with the social situation in Japan was mirrored in a recent survey. $76 \%$ of those surveyed said that Japan was not a good place to give birth and raise children (Chapple, 2004). Traditional gender roles are yet another aspect of the societal issues affecting fertility. Childrearing tends to be a female only task in Japan. Japanese men are rarely involved in household work, let alone assisting in childrearing. A study conducted by demographer Makoto Atoh found that Japanese husbands share of family work was conspicuously low. Time spent on family matters averaged only 20 minutes a day on weekdays (Akachi, 2002). The importance of the husband's share of family work could not be more paramount. A cross-national comparison of husband's share of family work showed that countries where husbands contributed more to family work tend to have higher fertility (Akachi, 2002) (Figure 6). 
Another aspect of this discontent is sure to come from comments such as the one made in January by health minister Hakuo Yanagisawa. In a speech encouraging women to perform a public service by raising the birthrate the minister said "Because the number of birth-giving machines and devices is fixed, all we can do is ask them to do their best per head" (McCurry, 2007). Another equally inappropriate sentiment was offered by former Prime Minister Hashimoto Ryutaro who "publicly expressed regret at the huge number of women entering formal education and thus, presumably, deterring them from their principal function in life, i.e. procreating" (Chapple, 2004). While it is obvious that not everyone shares the opinion of the former Prime Minister or Health Minister, it is apparently widespread enough to affect more than a few women's desire to have children.

The government has encouraged breaking down the fixed male and female roles and shifting toward a more shared responsibilities and dual parenting approach. Because of these fixed roles and attitudes the Ministry of Health \& Welfare's Advisory Council on Population Problems cited the "rectification of the stereotyped gender role division... as the main policy goal" (Atoh, 2000). It is beyond doubt that the social situation of Japan needs to be reevaluated. Attitudes, roles, and stereotypes must be changed. This will not be an easy task, but it is one that the government must tackle if it hopes to alter the downward birthrate trend. 


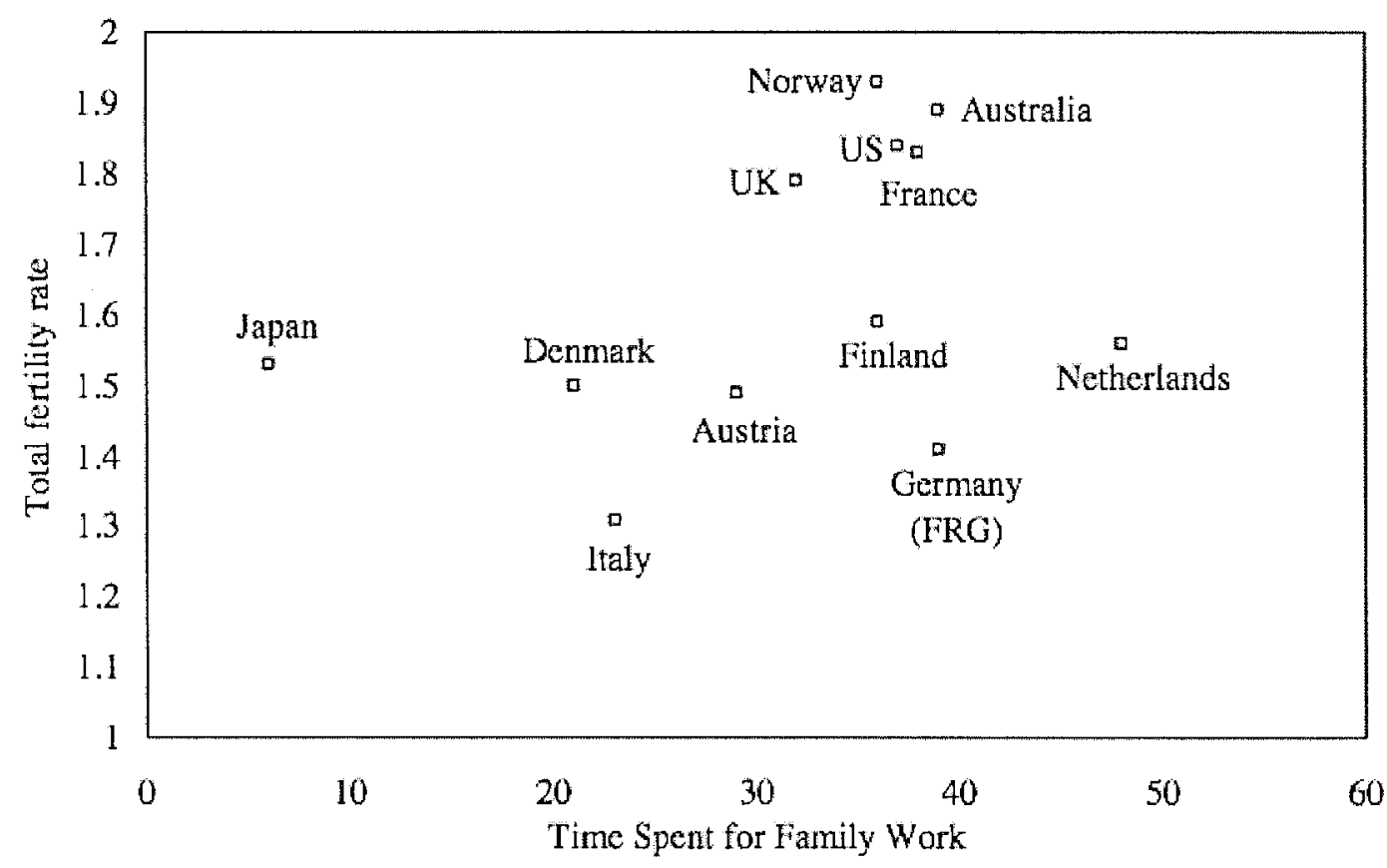

Figure 6. Relationship between TFR and Men's Time Spent for Family Work (1985-92). Source: UNDP, 1999.

\section{Economic Factors Affecting Fertility}

Economic issues are a factor affecting birth rate, and are far easier, as well as less controversial, for the country's leaders to address than many social issues. One of the initial ways that economics affects birth rates is through the decline in the utility of children. This is a natural result of nations making the transition from an agrarian, rural society to an industrialized urban society. This transition occurred in Japan during the early to mid part of the $20^{\text {th }}$ century and is not a direct factor leading to today's population woes, but it cannot be overlooked. More pressing than the decline in the 
utility of children is the incredible costs of raising children in Japan. According to demographer Julian Chapple, "many say they would like to have more children but can't afford to. The financial burden of having children is enormous and an obvious deterrent" (Chapple,2004).

Childcare and education expenses are both having a negative impact on fertility rates. Childcare costs are prohibitive in Japan, and this is one challenge that the government is attempting to resolve. Child allowance, tax cuts, subsidies, and increases in the number of childcare centers are all ways government is attempting to mitigate these costs. Education expenses are quite another matter. While the government pays for compulsory school, many families pay for services that extend beyond those provided at public schools. In Japan, much of a child's future depends on the schools they attend, so parents often pay for more expensive private schools hoping to increase their child's chances of success. Often, there is the added expense of $J u k u$, or private cram school, which most children attend after finishing their day at public school. Opinion surveys have consistently found education expenses to be the largest factor for Japanese couples to limit their family size (Akachi, 2002).

The economic climate of Japan over the past fifteen years has done little to help matters. Since the bursting of the Japanese economic bubble during the early 90 's, there has been a large degree of economic uncertainty exacerbating the problem of low fertility rates. To emphasize this, Professor of Population Economics, Naohiro Ogawa claims "increased economic insecurity reduced marital fertility in the 1990's" (Ogawa, 2003). Adding to this he states "women working as paid employees tend to be easily affected by the business cyclical factors through fluctuations in their wages, and thus adjust their 
reproductive behavior" (Ogawa, 2003). The downward trend of the Japanese economy has definitely been a factor contributing to the fertility rate's continued downward path.

\section{Policies Addressing the shrinking population and workforce}

\section{Fertility Policy}

It was not until 1990 that the government began to enact policies to counter the fertility rate, which fell below replacement levels in the mid 1970's. The results of a 1989 report by the Ministry of Health, Labour and Welfare revealed that fertility had fallen to an all-time low of 1.57. Prior to this report, the general public had little awareness of the falling fertility rate. As a result the findings of this report became known as the "1.57 Shock." Shortly thereafter, under the auspices of the Office of Cabinet Council on Internal Affairs, the government established an inter-ministerial liaison committee for "Creating an environment where people can bear and rear healthy children" (Atoh, 2000). This has remained the central theme of the government's approach to correct declining fertility: "government should promote the creation of a social environment to support young people who desire to marry and raise children" (Atoh, 2000).

Fully aware that fertility is deeply related to each individual's private life, the government has concentrated its efforts toward improving the environment for raising children rather than encouraging "making babies" (Chapple, 2004). To this end, the government has not issued any official documents stating a level of fertility it hopes to obtain, nor has it "limited any effective means of fertility control" (Atoh, 2000). Indeed government has gone to great lengths to stress that its policies are not pro-natalist, but 
rather are welfare and family policies. Historic reasons account for the government's stance. Leading up to WWII, Japan's leaders tried to fuel the war effort by urging women to produce as many children as possible under the slogan "umeyo, fuyaseyo" '(let's give birth! Let's increase [the size and strength of the nation!])' (Chapple, 2004). As a result, Japanese politicians are incredibly leery of creating too overt or forceful policies.

The policy responses to declining fertility have primarily been aimed at creating a more enticing and welcoming environment for having and raising children (Table 1). As such, the government set forth three basic guidelines dictating the aims of policy directed at declining fertility. These guidelines are "1) to keep harmony between family life and occupational life, 2) to improve living conditions (such as housing), and 3) to support family life and childraising" (Atoh, 2000). Table 1 lists the "major actions taken by the Government toward declining fertility" (Chitose, 2003). Most of these policies focused on issues such as child allowance, duration and wage compensation of parental leave, and increases in the number of childcare centers and the services they provide. As can be noted from Table 1 some of these policies have second editions. These upgraded and renewed versions portray the government's recognition that efforts must be intensified. For instance, the 'Childcare and Family Care Leave Act of 1995' increased the limits set by the '1991 Childcare Leave Act' regarding both the duration and percentage of wage compensation ( $25 \%$ to $40 \%$ ) available to them during parental leave (Akachi, 2002). The 'New' Angel Plan extended the eligibility for child allowance, and increased the number and capacity of childcare centers. Policies such as these, and the continued improvement 
of them, demonstrate the government's efforts to correct the decline in fertility.

However, despite these efforts the fertility rate continues to fall.

Table 1. Major Actions Taken by the Government toward Declining Fertility Rate. Source. Ministry of Health, Labor, and Welfare Annual Report

\begin{tabular}{|c|c|c|}
\hline TFR & TFR & TFR \\
\hline 1.54 & 1990 & $\begin{array}{l}\text { An inter-ministry committee "Creating a Sound Environment for } \\
\text { Bearing and Rearing Children established }\end{array}$ \\
\hline 1.53 & 1991 & Childcare Leave Act enacted \\
\hline 1.50 & 1994 & $\begin{array}{l}\text { The Angel Plan or the "Basic Direction for Future Child Rearing } \\
\text { Support Measures" (1995-1999) formulated. The "Five-Year } \\
\text { Emergency Measures for Childcare Services" planned }\end{array}$ \\
\hline 1.42 & 1995 & Childcare and Family Care Leave Act enacted \\
\hline 1.38 & 1998 & The amendment to the Child Welfare Law enforced \\
\hline 1.34 & 1999 & New Angel Plan (2000-2004) formulated \\
\hline 1.36 & 2000 & Child Abuse Prevention Law enacted \\
\hline 1.33 & 2001 & The amendment to the Employment Insurance Law enforced \\
\hline 1.32 & 2002 & $\begin{array}{l}\text { The "Measures to Cope with a Few Number of Children Plus One" } \\
\text { reported to the Prime Minister }\end{array}$ \\
\hline 1.29 & 2003 & $\begin{array}{l}\text { The Law for Measures to Support the Development of the Next- } \\
\text { Generation, the amendment to the Child Welfare Law, and the Law } \\
\text { for Basic Measures to Cope with Declining Fertility Society enacted }\end{array}$ \\
\hline
\end{tabular}

\section{Immigration Policy}

Immigration policy is another factor directly affecting Japan's population. With shrinkages looming in the working population, immigration is one way that Japan could mitigate the daunting demographic challenge now confronting it. However, Japan has traditionally remained averse to accepting foreign residents. In 2000 there were only 1.68 million foreign residents living in Japan, accounting for less than two percent of the total population (Karan, 2005). The pressures of the graying and shrinking population, which pose a serious threat to the competitiveness of the world's second largest economy, are causing Japan to rethink its attitude toward outsiders. 
For Japan to maintain its current level of economic output 600,000 foreign workers would need to be brought in on a yearly basis (Karan, 2005). According to the 2005 census, only $1.3 \%$ of Japan's working population $(770,000)$ is comprised of foreign workers (Hayashi, 2007). This is up from 0.9\% $(604,000)$ a decade ago, but is still a very small percentage. While it seems highly unlikely that traditionally closed and immigration resistant Japan will open the doors and allow in 600,000 foreign workers a year, changes in policy are occurring.

In April of 2006 the Council on Fiscal and Economic Policy, issued a report on the government's global strategy to reinvigorate the economy (Hisane, 2006). In order to help maintain high economic output in light of the current demographic crisis, the report calls for greater acceptance of foreign workers. The government is also to review the type of work available to foreigners, create more flexibility in hiring them, and seek new ways to attract more skilled workers. This shift in governmental policy, to encourage more foreigners to work in Japan, demonstrates the government's concern of maintaining Japan's competitiveness because of its shrinking working population.

\section{Conclusion}

That the Japanese population will, for the immediate future, continue to contract and grow older is certain. What is uncertain is the effect this will have on the society and economy of Japan. The drop in fertility is not the result of a single factor, but rather is the combination of many related issues. Social issues such as increased educational and career opportunities, and the phenomena of womb-strike and the parasite single affect fertility. Having a more adverse impact on fertility are the stereotypes of, attitudes 
toward, and assumed roles of women. Additionally, the economic constraints and difficulties play a significant part in further slowing fertility. The question of how the government should best handle this situation remains.

At present government policies have failed to halt the decline of fertility. If true solutions are to be produced, there must be a rectification of the social and economic disincentives limiting women's desire to bear children. Furthermore, a shift in the predominant mind-set dictating the roles and behavior of male and female relations must occur for changes to come about. Government is taking steps in the right direction, but these measures alone will not correct the problem. Fertility issues are, by their nature, a social and cultural phenomenon and the decisions concerning them are inherently personal. Policies are generally ineffective at addressing fertility, especially so when the government skirts the issue. New approaches for how to cope with the declining fertility rates must be conceived if there is to be a chance of reversing the trend and staving off Japan's impending demographic crisis. 


\section{References}

Atoh, M. 2000. The Coming of a Hyper-Aged and Depopulating Society and Population Policies: The Case of Japan. Expert Group Meeting on Policy Responses to Ageing and Population Decline. United Nations Population Division (September).

Atoh, M., M. Akachi. 2002. Low Fertility and Family Policy in Japan. Journal of Population and Social Security, Supplement to Volume 1.

Chapple, J. 2004. Dilemma Posed by Japan's Population Decline. Electronic Journal of Contemporary Japanese Studies 5 (October).

Chitose, Y. 2003. Policies Targeted to Families with Children: Policy Responses to Declining Fertility. Child Related Policies in Japan. National Institute of Population and Social Security Research (March). http://www.ipss.go.jp/sinfo/e/childPJ2003/childPJ2003.htm.

Center for Disease Control. 2005. National Center for Health Statistics-Marriage And Divorce. http://www.cdc.gov/nchs/fastats/divorce.htm.

Hayashi, Y., S. Moffett. 2007. Cautiously, an Aging Japan Warms to Foreign Workers. The Wall Street Journal (May 25).

Hisane, M. 2006. Japan Stares into a Demographic Abyss. Japan Focus 1864 (May). http://www.japanfocus.org/products/details/1864.

Inoue, S. 2001. Population Policies and Programs in Japan. Population Policies and Programs in East Asia, East-West Center Occasional Papers: Population and Health Series 123 (July): 23-37.

Karan, P. 2005. Japan in the $21^{\text {st }}$ Century: Environment, Economy, and Society. Lexington: University Press of Kentucky.

Kyodo News Service. 2007. 40.5\% of Population to be Seniors by '55: Report. The Japan Times (June 9).

MacKellar, L., Horlacher,D. 2000. Population Ageing in Japan: A Brief Survey. Innovation 13 (4): 413-430.

McCurry, J. 2007. Japanese Minister Wants 'Birth-Giving Machines', a.k.a. Women, To Have More Babies. The Guardian (January 29).

Ministry of Education, Culture, Sports, Science and Technology. Enrollment and Advancement Rate. http://www.mext.go.jp/english/statist/index01.htm. 
Ministry of Internal Affairs and Communications. Labor. 2005 Statistical Handbook of Japan. http://www.stat.go.jp/english/data/handbook/cl2cont.htm.

Ministry of Internal Affairs and Communications. Population. 2005 Statistical Handbook of Japan. http://www.stat.go.jp/english/data/handbook/c02 cont.htm.

Ogawa, N. 2003. Japan's Changing Fertility Mechanisms and its Policy Responses. Journal of Population Research 20: 89-106.

Population Reference Bureau. The 2006 World Population Data Sheet. http://www.prb.org/Publications/Datasheets/2006/2006WorldPopulationDataShee t.aspx

Scanlon, C. 2001. Japan's Parasite Singles. BBC World Service (May 31).

Smil, V. 2007. The Unprecented Shift in Japan's Populations: Numbers, Age, and Prospects. Japan Focus 2411 (April). http://www.japanfocus.org/products/details/2411.

Takahashi, S. 2004. Demographic Investigation of the Declinging Fertility Process. The Japanese Journal of Population 2 (1): 93-116.

Tolbert, K. 2000. Japan's New Material Girls: 'Parasite Singles' Put Off Marriage for Good Life. The Washington Post (February 10).

Zielenziger, M. 2006. Shutting Out the Sun: How Japan Created Its Own Lost Generation. New York: Doubleday. 